\title{
WILL WE KNOW IT WHEN WE SEE IT? CONTEMPLATING EMERGENT WORLD-SYSTEMS
}

\author{
Gregory P. Williams
}

With some exceptions, intellectuals in the world-systems tradition trust that the capitalist world-economy will not last forever. Less often discussed is how to identify the system or systems that will replace it. This paper takes up the topic of emergent world-systems by proposing criteria for identifying the end of capitalism and the rise of potential replacements. It does so in three steps. First, it lists two signs marking the conclusion of capitalism, including the end of the endless accumulation of capital and the end of nationstate dominance. Next, this study notes five factors for labeling emergent world-systems, including: (1) the location of boundaries; (2) the exchange of luxury goods; (3) the number of economic and political centers; (4) the presence of inequality; and (5), the character of ecological exploitation. This checklist can help determine whether a world-system is a world-economy, a world-empire, a mini-system, or some kind of unprecedented world-system. And finally, this paper cautions against relying on ideological narratives of a system as well as the labels assigned to workers. Common values may follow the functional formation of a world-system. This paper is also wary of shortterm trends, which often prove to be less important than they may initially appear. It concludes by remarking on the role of individuals in shaping the formation of world-systems.

Keywords: capitalism, nation-state, transformation, world-system.

In the classical view... laws of nature express certitudes... Once instability is included, this is no longer the case, and the meaning of the laws of nature changes radically, for they now express possibilities or probabilities.

Ilya Prigogine (1997: 4)

When a whale dies, its carcass sinks to the ocean floor and serves as a life-giving resource for other organisms. In fact, a large whale fall can provide the basic necessities for survival for up to seventy-five years. First, scavengers like hagfish and sea scuds spend several months pulling apart the whale's soft tissue. Then, worms feed off the tissue for several months or years. And finally, bacteria feed for decades off sulfur emitted from the whale's skeleton. ${ }^{1}$ Yet, the whale fall is more than mere food. Some fifty-five species live exclusively on whale falls. It is, according to one account, a whole 'planet' unto itself (see Radiolab 2011). It provides the context for interaction between various species that otherwise would not have come into contact with one another. The whale 
fall, in other words, is a self-contained system. And since the whale's resources are finite, the whale fall is also a historical system.

The story of the whale fall system is not unusual. In fact, social systems like capitalism also have lifespans, forming, evolving, and then ending. ${ }^{2}$ One advantage of the world-systems tradition is that it has applied the scientific study of systems to human interaction. As such it is a holistic tradition in the sense that it treats actors within social systems as interconnected pieces of a totality. ${ }^{3}$ Like sea scuds and hagfish, nation-states, international organizations, and economic development programs are part of an ecosystem. Even ideological beliefs like liberalism and conservatism, or views on whether humans should conserve minerals or establish national parks, are part of a larger system.

Today, there are (at least) three main branches of the world-systems tradition. ${ }^{4}$ One is world system history, which treats the Earth as a single system throughout time (or at least the last five thousand years). Such scholars include Andre Gunder Frank (1998) and Robert Denemark (1999). Another is the comparative world-systems perspective that sees systems as discrete but historically connected to one another across time, flowing like streams into rivers, lakes, and oceans. Its chief innovator is Christopher ChaseDunn. $^{5}$ And a third is world-systems analysis, which more or less understands worldsystems to be independent of one another over time. This view is most famously exemplified by Immanuel Wallerstein, who is also considered the 'father' of the worldsystems tradition. ${ }^{6}$

The latter two branches agree that capitalism is unique in that it has expanded to cover the whole earth. They differ on the origins of capitalism: for comparative scholars, as the historical (though not necessarily dialectical) evolution of previous systems; for world-systems analysts, as emerging from a kind of historical 'state of nature.' But they agree that the world was not always capitalist, and therefore, that it will not always be capitalist.

The end of capitalism has been the subject of much discussion and debate. ${ }^{7}$ Whether its successor (or successors) will be more or less exploitative than capitalism is also the subject of much discussion and debate. Less frequently discussed, however, is how to identify the world-system or series of systems that will replace capitalism. Unlike the whale, which is delivered all at once to the ocean floor, social systems take time to form. Thus, the nature of a post-capitalist system may not be obvious. This paper contemplates emergent social systems by drawing upon the comparative and analytical branches of the world-systems tradition. I argue that an infant world-system will not be beyond classification, but rather may behave according to a known type, whether seen in practice or only in theory. I see this work as a preliminary step towards understanding a post-capitalist system in its formation. Such an exercise, however designed, will be no substitute for hindsight. Systems are contingent creatures, subject to change, and may evolve considerably over time. Still, in a post-capitalist world, it will be natural for humans to want to understand the structures in which they exist. This paper anticipates that world, and the desire for information, without assuming when such a world will come into being.

The paper first discusses signs that capitalism has come to an end. Next, it reviews types of world-systems and offers five tips for recognizing emergent systems. Then, it 
offers some advice on those factors that may prove misleading, such as the narratives people invoke to describe systems. Finally, the paper concludes by acknowledging the role of humans in creating world-systems. Whereas bacteria must wait for a whale fall, humanity can shape new historical systems.

\section{Capitalism's End}

When thinking about new systems, we must first ask about our present circumstances. Before any new system can be identified, the old system must have reached its conclusion. Given the current system's longevity and global reach, it may be difficult to tell whether the capitalist world-economy has indeed passed. But this step is essential. Factors pointing to emergent world-systems are necessary but not sufficient conditions. If one can declare that capitalism is gone, then one can work towards discovering new systems.

Though many agree that the present is characterized by capitalist economic relations, there is widespread disagreement about what it means to have capitalism. Even though they had divergent conclusions, the authors of Does Capitalism Have a Future? settled on a common definition, which they took from Max Weber (Wallerstein et al. 2013). Capitalism, they decided, is a network of economic relations predicated on the endless accumulation of capital. ${ }^{8}$ By capital, one means stored value. Value can be stored in things like currency, property, minerals, and stocks. ${ }^{9}$ This functional definition avoids relying on wage labor, a popular alternative, and thus includes various types of forced labor that occur today. Moreover, from this perspective, the modern states system is not in competition with the capitalist economy. Rather, the modern state historically evolved alongside capitalism, in a kind of symbiotic relationship. Changes in these basic economic and political dynamics of capitalism may signal an end to the system.

\section{End of Endless Accumulation}

There was certainly capital accumulation in premodern systems. But capitalism is unique in that humans, on their own or through firms, must endlessly acquire more and more capital in order to survive and thrive. In this usage, survival means continued existence, whereas thriving means an existence that is reasonably comfortable (for the system, anyway) and has relatively predictable patterns of behavior. In this image of capitalism, the productive functions of a firm (whether for shoes, for computer chips, or for insurance policies) are secondary to ensuring an increased rate of capital accumulation. For Wallerstein, the notion of amassing capital for the purpose of amassing capital is surreal: 'Capitalists are like white mice on a treadmill, running ever faster in order to run still faster' (1995: 40).

World-systemic scholarship also claims that capitalism began in Europe and the Americas in the 1500s, and expanded to cover the entire Earth. Although there is not space for a comprehensive review, it is important to note that expansion was not merely a sign of success. Geographic expansion has in fact been necessary for capitalism's survival. As conditions arose to threaten the survival of the world-system - conditions like resource scarcity and labor uprisings - the system would relieve internal pressures by incorporating external zones with fresh materials and a new workforce that was unprepared for exploitation. ${ }^{10}$ But once capitalism extended to cover the whole planet, the 
system had to develop new ways to relieve the pressure of geography. Over the last century or so, capitalism has expanded by commodifying previously non-commodified goods, such as education or healthcare. Capitalists have also grown adept at creating new commodities, such as various internet goods or the derivative trade, the latter of which mirrors the price alterations of real goods. Furthermore, large-scale businesses have found new ways to reach oil, copper, and other resources hidden deep in the earth. ${ }^{11}$ Thus, there is reason to think of the present as an unusual, perhaps unprecedented, moment in the history of the capitalist world-economy.

The most telling sign that capitalism has ended will be when firms and individuals need no longer to ceaselessly accumulate capital. Acquiring capital to acquire more capital will not be a necessity. In this regard, we should consider the actions of the capitalists (Wallerstein 1984: 565) - that is, the owner-producers, entrepreneurs, and bankers who benefit the most from a capitalist system. Under the modern world-system, such actors sought profit maximization by minimizing production costs like wages, safety precautions, and environmental protocols. Competition, though good for consumers, often (but not always) threatened profit maximization. Thus, in the absence of stateinterference, the long-term trend was towards consolidation of firms, creating a few major companies within an industry. If the beneficiaries of capitalism no longer adhere to the rules of capitalist practice, then perhaps they are no longer capitalists.

In practice, identifying the end of endless capital accumulation is fraught with measurement problems. One metric to avoid is how individuals understand their own circumstances. In other words, although human behavior is essential to the functions of world-systems, individuals may not be consciously aware of the larger processes around them. Worms, after all, need not be aware of the whale's life in order to feed off its soft tissue. Although humans are rather different organisms, they are like creatures feeding on a whale in that they, too, do not need to be aware of the larger system in order to perceive their interests. Moreover, grasping the nature of larger structures may prove difficult in the movement; something closer to a complete understanding arrives with hindsight. Thus, measuring the end of capitalism through the psychology of individuals may not be useful. Even though humans can be expected to advance their interests, one cannot expect them to intuit the larger world-system.

Another factor to steer clear of when looking for the end of endless accumulation is the persistence of institutions into a post-capitalist era, even institutions directly associated with capitalist processes. Under capitalism, retailers, banks, insurance companies, and financial firms rise and fall with great regularity. Even the fall of large or longstanding firms like Bear Stearns, which collapsed in the crisis of 2008, may not be momentous from a world-systemic perspective. Moreover, there are at least a couple of reasons to think that some firms would persist into a post-capitalist world. One is that people at the firm, with survival in mind, may redirect its attention to new behaviors. ${ }^{12}$ And another is that firms are zones of technological innovation, and indeed could become vital to an emergent world-system. Skeptical readers might associate firms with a capitalist ideology (e.g., the 'free market'), but, as Robert Paul Wolff puts it, changing 'a planning system in our carton factory does not require the development of socialist consciousness' (2012: 1420). Or, the daily functions of a workplace may not be all that 
ideological after all. In short, when it comes to the end of endless accumulation, scholars should look at what people do, not what they say, or think, or where they work.

What then, should social scientists use to measure the end of endless accumulation? There is no easy answer. Wild stock market swings may be a sign of the destruction of a system, or, they may be a normal pattern of boom and bust phases. The same might be said of the extent of sovereign debt, including its effects on trade integration (and the 'deindustrialization' or 'deglobalization' processes) (Suter 2012). Other possible signs of the end of endless accumulation could include large shifts in wages, demand, or prices. ${ }^{13}$ This final category, prices, was the preferred measurement for Nikolai Kondratieff, who sought to explain capitalist development in terms of 'long waves' of forty-five to sixty years. ${ }^{14}$ Yet here, too, one might expect a tumultuous period to return to normal, which has historically been the case. Thus, it may be best to measure the end of endless accumulation through very long-term trends, having to do with the evolution of the world-economy over its entire lifespan. In this perspective, the end of endless accumulation would be a breakdown of patterns that have conventionally been considered predictable and even stabilizing for the capitalist world-economy. By breakdown, I mean an inability to return to some pre-crisis normal (see also Arrighi and Silver 2001). Whether measured in terms of prices, or trade, or demand, or some other factor, a shift away from previous multi-decade cycles could be a sign of a system that has gone into crisis.

Some authors believe the modern world-system has already gone into a crisis of accumulation (see, e.g., Amin 2011; Chase-Dunn 2013; Wallerstein 2013). Nonrenewable resources like oil, copper, nickel, and gold prove increasingly more difficult to extract (Klare 2012). Moreover, it remains challenging to secure a steady supply of cheap labor. ${ }^{15}$ When faced with twin pressures of resources and restless laborers, companies have preferred, as Wallerstein writes, to 'runaway' to new places (Wallerstein 2013). But today there are declining supplies of natural resources and fewer places to relocate. In response, capitalists have sought profits by other means, such as increased automation or shifting to the financial services market (Silver 2013). The exacerbation of these long-term trends could signal a system in crisis, unable to return to its normal behavior. According to Slavoj Žižek, the world ecological crisis (including the climate crisis) and persistent global economic turmoil, represent two of the 'four horsemen' of the capitalist apocalypse. ${ }^{16}$

However measured, the end of the endless accumulation will be signaled by the behavior of actors within the system. It will be identified by a breakdown of long-term trends, by which I mean the normal ways of doing business. The end of routine patterns of behavior in creating goods and conducting trade could be destabilizing (or, rather, a sign of instability). In such a breakdown, individuals will attempt to provide for their personal safety and secure some kind of predictable life for the future. They may participate in capitalist firms, yet their ability to survive will not depend on such participation.

\section{End of Nation-State Dominance}

There has been an extensive debate about the transition from feudalism to capitalism, and what holds the present system together. ${ }^{17}$ Generally, however, scholars agree that we live in a capitalist global economy whose principal political players are nation- 
states. I join those who consider the rise of the nation-state to be no accident: the nationstate system arose simultaneous to capitalism in a mutually reinforcing dynamic. ${ }^{18}$ Therefore a decline in nation-state efficacy vis-à-vis other governing entities (such as international organizations, local governments, corporations, resurgent imperial bureaucracies, or even feudal-style lords) would also be a sign of the modern world-system in crisis. Yet, here too we should proceed with caution. There may be reason to think that states themselves will not disappear. Paradoxically, state institutions may be capable of adapting to a changing world. Thus, we are looking for signs that nation-states have lost their dominance in the world-system, not their ultimate demise (i.e., the end of states as institutions).

Prior to the capitalist world-economy, the political boundaries of most worldsystems geographically coincided with their economic boundaries. For Fernand Braudel, states in the early sixteenth century - that is, at the start of the modern worldsystem - did not fully understand that the boundaries of governance (what we call the political realm) were smaller than the boundaries of trade (what we call the economic realm). There was, according to Braudel, something of a learning curve: 'The age of economic conquests had arrived, although contemporaries were not yet aware of these hidden realities' (Braudel 1982: 515). Spain proved to be the test case that showed others what to avoid. Charles V's failure to push Europe (which was most of the system at the time) under his control demonstrated that in the modern world there were economic limits to political power. For a contrasting case, Braudel refers to the rise of Dutch hegemony, which came into being through a rather different route. Rather than extend its political authority by integrating neighbors under a single bureaucracy, the United Provinces became the finance capital of Europe. The Dutch, however, did not aspire to recreate an earlier era of European unification: with more modest goals, they sought dominance but not state institutional control. Braudel concludes: 'What the Emperor Charles V never achieved - the conquest of Europe - Antwerp managed easily' (Ibid.). The new game, he notes, was 'played on an infinitely wider plane than... that of the state and its particular preoccupations' (Ibid.: 554).

Other states followed the Dutch model. This is not to say that all dominance became economic. Indeed, there was no shortage of wars, and the drive to wage war may have sped up the development of state bureaucracies (see Creveld 1999: 336). Nor was there any shortage of imperialism, which served as a way for European powers to develop economically and gain prestige among their peers. Instead, other states followed the Dutch model in the sense that they realized the modern world-system was different than previous systems. Even if they could achieve total dominance within their borders, leaders knew that conquering the world-economy was impossible. Leaders recognized that no king could follow in the steps of Charlemagne, who exerted complete (or nearly complete) control over the Holy Roman world-system. ${ }^{19}$ No modern state could establish total control on a world-scale. Thus the battle among states was to achieve unrivaled, though limited, power in the world-system.

In the modern world-system, the relationship among states has been anarchic, meaning that it is without central rule, but not chaotic, meaning a total lack of order (via organizations, agreements, or norms) (Arrighi 2010: 31). Inter-state competition led to successive waves of hegemony. The Dutch gave way to the rise of the British, whose 
naval investment yielded far greater returns than France's investment in a powerful land army (Ibid.: 28-85). Then, the British gave way to the Americans, who achieved unrivaled dominance with the defeat of the Germans in the mid-twentieth century. ${ }^{20}$

In the twenty-first century, with American supremacy waning, the U.S. pivot to Asia suggests a new passing of hegemonic power. Yet, Wallerstein pushes back against this interpretation. He sees the contemporary crisis of endless accumulation as evidence that there will not be a fourth instance of hegemony in the capitalist world-economy (Wallerstein 1983). Other scholars have made similar observations from examining state behavior. Even strong states, according to writers like Susan Strange, became less efficacious over the course of the twentieth century. For Strange, states are having difficulty maintaining their dominance over markets (Strange 1996). Although politicians often proclaim the virtues of free trade, the history of the nation-state has mostly been a history of mercantilist behavior - that is, states asserting themselves into international trade. Such state-intervention in fact greased the wheels of commerce by enforcing contracts, managing currency, and overseeing property transactions (Wood 2002: 179). Some scholars believe that changes to the nation-state system, paired with the rise of international organizations and international law, is already leading to a new form of global governance. ${ }^{21}$ Such a conclusion might seem absurd in the present age, given the capacity of great powers to wage war and monitor their citizens. But history has shown that truly powerful actors do not need to prove they are powerful (Wallerstein 1980: 60). After all, it were the minor powers in Europe, France and England, who in the seventeenth century adopted mercantilist economic policies and also invested heavily in their militaries. The United Provinces achieved hegemonic power without needing to undertake the same efforts (at least on the same scale) (Ibid.: 37-71). Like deep sea creatures feeding more furiously, widespread governmental surveillance and datamining may be signs of states concerned for their future. ${ }^{22}$

If nation-states are indeed in decline, how can one identify the point at which they are no longer the dominant political players in the world? The crucial factor appears to be that point when states lose primacy of governance within their borders. By this, I mean the end of the historical functions of the state, including: dispute resolution, security and safety provisions, taxation, and roads and other infrastructure. The key is not whether such goods are provided by the public or the private sector, but whether the state has the power to determine how goods are provided. In short, the issue is whether states globally can maintain a monopoly on social control. It would not be enough for a single state to fall by revolution, military coup, or invasion. These activities are routine. To mark a fundamental change in the modern world-system, governance would have to move away from states to other institutions on a world-scale.

There are three potentially overlapping directions in which political authority can move: (1) upwards, towards international organizations, global empire, or even worldgovernment; (2) laterally, towards a neo-feudal framework with multiple and overlapping sources of political authority; and (3), downwards, towards localities and major cities (or city-states). ${ }^{23}$ These directions could be combined, such as a push of political power upwards to a global trading empire managed by elites based in a few large cities, with some governance shifted downwards to subnational provinces. However, config- 
ured, a move in any direction would mean that nation-states had lost their dominance, and therefore, that a fundamental change of the world-system had occurred.

Still, state institutions do not have to disappear to mark the end of the modern world-system. Future world-systems may or may not have states or other institutions. In addition to states, institutions like businesses, nonprofits, political parties, and religious organizations may find a way to survive through world-systemic transition. Like the humans that run them, institutions prioritize continued existence. ${ }^{24}$ One institution of note is the Catholic Church, which, although known for being slow to change, has proven remarkably capable of adaptation. Perry Anderson notes that 'the Roman Church has survived every other institution - cultural, political, juridical or linguistic historically coeval with it' (Anderson 1974a: 131-132fn11). The Church's bureaucratic size and landholdings allowed it to endure (perhaps even cause) the transition to feudalism. Centuries later, observers might not have expected it to last into the modern world. And yet it has witnessed the arrival of capitalism, the assertion of Westphalian sovereignty, land reform, and the transition to democracy. Other institutions, states included, may also find ways to adapt in the next transition.

Skeptical readers may see a contradiction: on the one hand, that capitalism and states came about at roughly the same time and have a mutually beneficial relationship; yet, on the other hand, that capitalism may predecease the states. A resolution rests in identifying what is coming to an end. While the states may (or may not) survive, the inter-state system as we know it will not. Just as we are looking for an end to the endless accumulation of capital, not the end of capital, we are also looking for the end of nation-states as dominant political actors, not the end of state institutions. States may be able to learn new behaviors and adjust to a changed world. Like fish swimming from saltwater into freshwater, states will have to adapt if they are to survive.

It may be too early to determine where governance is moving (up, across, or down). But a move in any direction will likely demonstrate the conclusion of the modern world-system. The major development would not be the end of the nation-state as an institution, but rather the end of its foundational importance to the modern world-system. Such a change would mark a period of transition between systems.

If the economy reaches the end of endless accumulation, or if states are no longer the dominant global actors, then the modern world-system will have passed. The next step will be to determine the character of the world-system or systems that replace it. Many of these factors, however, are necessary but not sufficient conditions for diagnosing world-system type (and some could occur within an overall capitalist framework).

\section{Indicators of Emergent Systems}

If in the future we determine that the capitalist world-economy has ended, then how will we go about defining the post-capitalist system (or systems)? A post-capitalist system might look similar to one from the past, or, it might be an unprecedented. This section first describes types of world-systems, and then outlines a series of factors that may help identify an emergent system. 
According to the comparative and analytical branches of the world-systems tradition, at least four types of world-systems have previously occurred. ${ }^{25}$ The smallest were the various hunter-gatherer world-systems. These were small-scale, kin-based communities without states and usually without classes as they are understood today. Though everyday life varied greatly from one system to the next, in some cases, forager and hunter-gatherer world-systems were relatively egalitarian. There were disparities of power and privilege, but positions of power in such systems was usually acquired through persuasion, not coercion, and individuals in such positions could be removed by the group (Chase-Dunn and Lerro 2014: 81-82). Such systems also relied upon a network of generalized or institutionalized reciprocity: instead of transactional exchanges based on labor and other costs, there was a sense of personal contribution to the larger social group (beyond one's immediate relatives) without expectations of being repaid. Yet, as Chase-Dunn and Lerro explain, such systems were not founded on altruism: strong cultural norms opposed personal acquisitiveness; and, in nomadic societies, people could only possess what they could carry (Ibid.: 83). In their caution lies an important lesson: we should be careful not to romanticize small scale 'indigenous' systems. The reciprocity systems of several thousand years ago occurred in a context that may be difficult to replicate today, let alone universalize for a post-capitalist globe.

At a somewhat larger scale were kin-based world-systems composed of chiefdoms. Kin-based chiefdoms were larger than hunter-gatherer systems, possessed a more stable (possibly hereditary) leadership and were hierarchically organized. By hierarchy, I mean class divisions of any number, based on social status and beliefs of superiority. The chief and those close to him managed a good deal of everyday life, including food resources, land, and even reproduction (Chase-Dunn and Lerro 2014: 104).

Still larger were the world-empires that consisted of a single governing authority for an entire economic system. They were at times massive systems, capable of expanding across continents, ruling over millions. In fact, at their respective peaks, the Roman Empire and Han China each had nearly sixty million inhabitants. Too large to be administered in person, world-empires of the past had sizeable bureaucracies that often overlay local styles of rule (Anderson 1974a: 53-103; Wallerstein 1974a: 15-17). Some regions faired reasonably well, and others did quite poorly. This axial division of labor, in which the well-off 'core' zone dominated over the immiserated 'periphery,' was reinforced by ideological, and cultural and religious beliefs. Extraction of tribute from the periphery was secured by the semiperiphery, an in-between zone that served as both a hub of economic exchange and political guarantor against anti-systemic uprisings. ${ }^{26}$

The largest type of world-system to come into being was a world-economy, a form that has survived infancy only once, avoiding the usual conversion into a world-empire (Wallerstein 1974b: 390-391). Structurally the two have much in common, including an including an axial division of labor, hierarchy, inequality, and exploitation. A major difference set the current system apart: the disproportionately-sized economy covering multiple political authorities. Were it not so familiar to us, the notion of a worldeconomy would seem strange. But, nevertheless, the capitalist world-economy has grown much larger than all other world-systems before it (Wallerstein 1989). Capitalism has extended across the entire globe, beyond the control of even the most powerful political entities (the nation-states, as we saw above). ${ }^{27}$ 
Perhaps thinking about the exploitative nature of many societies, scholars have also written about the world-systems they would like to see, even though such systems have no historical precedent. One is a socialist world-government, which Wallerstein in the 1970s anticipated would arrive after the collapse of capitalism. He saw this system as a single political and economic entity that, unlike its large scale predecessors, would be neither redistributive (like world-empires) nor capitalist (like the present worldeconomy) (Wallerstein 1974b: 415). With time, Wallerstein tempered his expectations. He began to write of another theoretical type of world-system, left unnamed because it could take many political, economic, or cultural configurations. It would be a system, however, that is 'relatively democratic and egalitarian,' based on a decentralized network of nonprofit organizations (Wallerstein 1998: 69). Later, Chase-Dunn imagined a democratic socialist world-system dedicated to ecological protections, population controls, and a more just economy. For him, the threat of nuclear destruction might lead to states, collectively, to create a world democratic federation (Chase-Dunn 2003).

A post-capitalist world-system may adhere to one of the types above or could even be a totally new kind of system. Here, I propose five key identifiers of world-system type: the size of the smallest geographic area to provide necessities for life; the exchange of luxury goods; the number of economic and political centers; the degree of inequality; and the rate of ecological exploitation. These factors have been important for identifying previous world-systems. Thus, if we find ourselves in a situation without the capitalist world-economy, these questions may point in the right direction.

In moving down the list, it may be tempting to look for 'nested' systems, by which I mean world-systems within world-systems. In this manner, social relations differ greatly from biological relations: two world-systems cannot take up the same space at the same time. World-systems are sometimes called totalities because they are comprised of many interlocking factors: material processes, social behavior, and institutions. As Anderson put it, the parts of a totality are intertwined 'in such a way that any one of them considered separately is an abstraction' (Anderson 1992: 58fn12). Thus, the concept of social system nesting is incompatible with most writings within the world-systems tradition.

\section{What is the Smallest Geographic Area Providing Necessities for Life?}

Systems like a whale fall cannot substantially change in size. Limited by the whale's resources, the system occupies a fixed space. In other systems like salt water marshes or the universe, which may change in spatial breadth, spatial size is not determined by the behavior of the actors within them. Yet social systems are different not only in that they are capable of expanding and contracting, but also in that the actors within the system (such as humans or states) can alter their geographic range. The capitalist worldeconomy began at the continental level but today could not possibly consume a larger geographic zone. Still, we should not think of world-systems as large by definition, always involving numerous connections across the globe. Rather, world-systems are defined by their smallness. What is the minimum number of connections that deliver all the necessities for life? How are food, clothing, and shelter provided?

Historically, according to Braudel, identifying the borders of a world-system has been a relatively straightforward process. For him, systems were usually surrounded by 'quiet zones,' a space where no system exists: 'They are like thick shells, hard to pene- 
trate; they are often natural barriers, no-man's lands - or no-man's seas' (Braudel [1979] 1984: 26). The borders of more recent systems, however, prove challenging to draw. What constitutes a quiet zone? For example, the early centuries of the European worldeconomy coexisted alongside a Russian world-empire (Wallerstein 1974a: 313-324). People in one world-system knew about and had contact with people in the other, but they were not interdependent (that is, they did not need one another for survival). Likewise, political processes were mostly self-contained: outcomes in one area for the most part did not rely on what happened in neighboring areas. Nonetheless, invasions by the Swedes, Poles, and Tatars in the sixteenth and seventeenth centuries may have facilitated the consolidation of power in Russia (Anderson 1974b: 356). In short, world-systems are mostly, but not completely, self-contained entities.

Now imagine two whale falls relatively close to one another. Are we dealing with one system or two? This is something closer to the problems of locating the boundaries of emergent systems on a crowded planet. With global population expected to be just shy of ten billion by midcentury, ${ }^{28}$ and with the seeming eradication of geography by telecommunications and the internet, some might assume that future world-systems will necessarily be global. But a sizeable population and global internet would not be sufficient for describing the planet as a single system. Such a system would have to involve the physical movement of goods from one place to another. It is not entirely unthinkable that the trading of goods necessary for life would take place over a space smaller than the size of the Earth. Thus, future world-systems may or may not occupy the entire globe.

For Braudel, the borderland between systems occurred when trade between zones becomes cost-prohibitive. If merchants, broadly defined, by and large rely on resources nearby, and find it against their interests to ship goods to far-away places, then their world-system may be limited in geography. Scholars should perhaps begin with urban areas, and examine where in the world cities acquire resources. If urban areas import from across the globe, as they currently do, then we may be once again in a single world-system. By locating boundaries, we may tell whether we are living in something resembling a small kinship-based system or something large, like a world-empire.

\section{Where are Luxury Goods Transported?}

Although world-systems are self-contained entities, observers recognize that there may be contact, even trade, between neighboring world-systems. Thus it may be helpful to keep in mind that a world-system provides necessities (or staples), not luxuries. Yet, the difference between a necessity or staple and a luxury good changes with time, depending on the availability of goods and social norms. ${ }^{29}$ In the early years of the modern world-system, luxury goods consisted of pepper, spices, silk, rugs, and jewels and other precious objects. Staple (non-luxury) goods were things like grain, cattle, fish, and wood (Wallerstein 1974a: 40-52). With industrialization and automation, the price of many goods has declined. For example, although cotton may have been a luxury good in the early modern world, today it would more likely be considered a staple. Therefore, in post-capitalist systems it may be useful to distinguish luxury goods in part by the availability of the item rather than its utility. After all, Coca-Cola serves no dietary purpose but its availability makes it a non-luxury good. Yachts, on the other hand, are sold in smaller numbers and almost always to buyers from upper classes. For a product to be a luxury good, according to Wallerstein, it would have to be sent in small shipments 
over long distances and be consumed by social elites. He writes: 'It was trade which benefited from price disparities and depended on the political indulgence and economic possibilities of the truly wealthy' (Wallerstein 1974a: 20). Measuring the networks of luxury good shipments may reveal zones external to the world-system. Conversely, measuring the networks of bulk good shipments may point to zones internal to the world-system. In short: although luxury goods may be traded among world-systems, shipments of staples occur within world-systems.

\section{How Many Economic and Political Centers Exist in the Geographic Zone?}

While thinking about the geographic range of an emergent system, scholars should consider the institutions at work. If the world-system is geographically small, then some kind of neo-kinship system might be in place. If the world-system is geographically large, then kin-based systems can be ruled out.

Assume for a moment that the world-system is geographically large. If a single governing authority spans the entire economy, and collects tribute from its subjects, then the new system may be a world-empire. If there are multiple political governing authorities within a single economy, then the new system may be a world-economy (like the modern world-system). In either case, we might see differences in the quality of life among various places. Uneven core/periphery exchange has historically occurred in both world-empires and world-economies.

If exchange is based on networks of reciprocity or conducted via nonprofits, and if authority is democratically selected and impermanent, then some kind of egalitarian world-system may be in place. This could be under a new institution, or it could take the form of an existing international organization (e.g. the United Nations), imbued with new powers.

\section{Does this System Possess Inequality?}

The presence of inequality, loosely defined as a condition whereby some individuals live in very well and many others live poorly, does not by itself indicate what kind of world-system has formed. Almost all world-systems have possessed inequality, albeit through different mechanisms: in premodern Europe, property determined class divisions; in the modern world, it was one's personal economic fortune. Social stratification according to status groups, which Max Weber defined as honorific positions (Weber 1946: 180-195), could also be indicative of inequality. Status might come in many forms, determined by wealth, ethnicity, gender, or even by beliefs about personal fortitude (e.g. knighthood). A system that lacks inequality will be, historically speaking, rare and quite possibly fragile. But if inequality is absent, one can rule out all previous largescale world-systems, and the emergent system will have almost no precedent.

\section{What is the Character of Ecological Exploitation?}

Although ecological degradation began long before the modern world-system, the capitalist world-economy accelerated ecological destruction. Long considered inextricably linked, human beings parted ways with the concept of nature the modern world. This may be due to the separation of food from food-getting. According to Harriet Friedmann (2000), it was in modernity that humans have been able to take food for granted. Capitalism led to the formation of food hierarchies, whereby food gathering was 
thought better suited for lower status groups, such as minorities, women, or laborers (Ibid.: 481). This was a drastic break from feudalism, whereby monastic orders associated agrarian work with God's will (Anderson 1974a: 135). Over time, the humanenvironmental divide grew - a separation that made it possible to justify the irreversible exploitation of nature. Food became one of the 'Four Cheaps' of capitalist industry, alongside energy, raw materials, and labor (Moore 2010). Thus, even though economic and natural processes were intimately connected, it appeared as though they were distinct and even in competition with one another. Environmental protection, according to one narrative, came at the cost of economic growth. Such an explanation became quite popular for owner-producers, who had an incentive to cut costs.

Events of twentieth century exposed contradictions of the economic-ecological distinction. Cost-cutting was, in truth, cost-shifting from owner-producers to governments. In the late twentieth century, states would pick up the tab (if they could afford to do so) to achieve clean air and water. Non-renewable resources such as oil, copper, lead, and mercury have been pushed beyond peak production, and are no longer readily available. And air toxins have warmed the planet beyond sustainable levels and threaten the survival of many species, including humans. The capitalist worldeconomy is simply reaching an ecological limit. For Jason W. Moore (2015), such developments are not by-products of the system: capitalism is in fact a way of organizing nature, by which he means both human nature and extra-human nature (the socalled 'environmental' realm).

Unlike whale fall systems, human systems are affected by their predecessors. Undisturbed natural places have infinite possibilities. But once a wild place is converted into a coal mine or a shopping center, it cannot be turned into a nature preserve, at least in the near-term. ${ }^{30}$ Increasing entropy, or waste, limits the possibilities of an area. ${ }^{31}$ Though we cannot know how future societies will relate to the environment, the legacy of capitalism will limit their choices. Many previous world-systems exploited material resources. But in a post-capitalist world, much of the natural world - including agricultural land, fisheries, and minerals - may be damaged or destroyed to an unprecedented extent. On the one hand, we might expect emergent world-systems to have a lower rate of ecological destruction. But on the other hand, emergent world-systems may form around securing resources, once again for the purposes of consumption. Nevertheless, how a system adapts to its ecological inheritance may give observers some sense of its functional elements.

The character of ecological exploitation, when combined with the other factors listed here - the search for geographic boundaries, the trading of luxury and necessity goods, the number of economic and political centers, and the check for inequality - can aid scholars in determining what kind of system or systems have replaced capitalism. The major effort will be to determine how many world-systems exist on the planet, their geographic range, and what type of system they represent. At the risk of understatement, everyday life will be rather different in a world-system based on reciprocity, tribute, or profit. All of these factors may prove difficult to measure, however, even if one has determined that the modern world-system has in fact come to an end. 


\section{Pitfalls in the Search for Emergent World-Systems}

Many other factors might point scholars towards identifying a world-system, such as ideological narratives and the juridical standing of laborers. Yet explanations derived from these indicators may prove to be more like shadows on the wall than representations of reality. In addition, we should be generally skeptical of large conclusions from short-term trends: world-historical change might appear sudden but will have long-term causes.

\section{Ideological Narratives}

We do not know if hag fish or worms debate ideas. We do know that answering this question matters very little for the creation of the system in which they live. Human systems are different in that beliefs about fairness, hard work, property, and many other things inform the actions of people. But the whale fall analogy is more relevant than one might assume. Many system-wide beliefs under capitalism did not come about until long after the system had been established (Wallerstein 1989: 50-53). By system-wide beliefs, I mean those widespread ideas about political equality, the division of labor and the distribution of resources that serve as rhetorical justifications for systemic outcomes. Thus, to draw a rather crude distinction, it may be best to think of system-wide beliefs as consequences rather than causes of world-historical change.

If the development of the modern world-system is any guide, we should expect post-capitalist system-wide beliefs to come about relatively late. According to Wallerstein, Europeans before the French Revolution by and large relied on feudal narratives of labor, protection, and fidelity. The structural processes of profit-maximization had been in place for some time before there was any rhetorical justification of such processes. But, as Wallerstein explains, 1789 represented a shift in thinking: political change became normal and political power was held by everyday people (2011b: 143217). Frightened at the prospect of losing power, controlling classes devised response strategies to delay the rates of political change and investment of political authority. The nobility preached conservatism, which emphasized order and cautioned against moving too fast too quickly. The bourgeoisie espoused liberalism, and advocated for a moderate pace of social change. And after some time, the lower classes adopted radicalism, and demanded that groups excluded from the political process (including Blacks, women, and workers) be allowed to exercise their political rights (Ibid: : 77141). According to Wallerstein, liberalism won the fight of the nineteenth century. Liberalism was, in his view, the ideal cover for capitalist exploitation because it spoke of equality while ensuring that progress was only glacially realized. Marginalized peoples could reasonably expect incremental inclusion in the political process - not now, of course, but at some point in the future (Ibid.: 21-75). In the twentieth century, liberals promoted values of national self-determination and economic development that, they claimed, were best realized with help from the Global North. Even the most exploited of peoples, in fact, were in a position to defend capitalism if they believed in the virtues of personal sacrifice, hard work, and delayed rewards. ${ }^{32}$ As the current system declines, liberals may shout even louder as their previously dominant ideas become increasingly less realizable, and therefore, less believable. The resurgence of populism in recent years, however, means that the right as well as the left are no longer tethered to the center (Ibid.). 
How long will capitalist ideas persist into an emergent system or systems? On the one hand, if the narrative of feudalism (which promoted social hierarchy and inequality) could last for centuries after the end of the system, the narrative of capitalism could also endure. And proponents of capitalism have outdone feudalism by developing a friendly narrative for the world-system, promising equality and material well-being. On the other hand, feudal ideas persisted in part because power was invested in authorities held at a distance from the masses. If democracy lasts into the post-capitalist world, and if technological communication remains fast-paced and easily accessible, system-wide ideas could shift more quickly than in the past. Regardless, ideational change may not be indicative of world-system type.

\section{Labels Assigned to Laborers}

Like ideologies, the juridical standing of laborers may serve to obscure rather than reveal characteristics of an emergent world-system. This assessment may be controversial for those who track world-historical change by the descriptive labels we assign to workers. ${ }^{33}$ For such thinkers, it matters whether workers are designated as slave, serf, corvée, or wage. And undoubtedly such distinctions are meaningful for those engaged in forced labor. But for the purposes of classifying a world-system, it is more important to look at the social context in which the labor takes place. For whom, and for what purpose, does the labor serve? Take, for example, slave labor. In the ancient world, slavery was determinative for the mode of production. Under modern capitalism, however, slavery in the southern United States was part of an overall capitalist global economy. According to Anderson, the American south was in fact only able to continue using slaves after the abolition of the slave trade - taking on the expense of growing the slave population because it occurred within the context of American wage-labor capitalism (Anderson 1974a: 77-78fn36). Owner-producers created goods, at a high and brutal cost, for an international capitalist market. Even after slavery was formally abolished, forced labor continued. Today, in many parts of the world, sex workers, fisherman, and construction laborers are subjected to unfree, non-wage, labor within the context of a capitalist world-economy. Thus, the juridical standing of laborers may say very little about the functional attributes of the world-system.

\section{Short-Term Trends}

Much social scientific research is oriented towards the near term, that is, to understand present-day challenges. This is often useful, given changing technological and geopolitical conditions. But the short term can be misleading. Historians of the mid-twentieth century knew this lesson well. E. H. Carr (1961) famously warned of exaggerating the near-term, and, by noting that historians are themselves interacting with history, taught that clarity may only arrive with the passage of time. In practice, this lesson is less than obvious. Monumental events can appear to have greater world-historical importance than time will bear out. After all, the fall of the Soviet Union, to some, appeared to be nothing less than the 'end of history,' a permanent victory for liberal capitalism because it had no enemies in sight (Fukuyama 1992). Today, the events of 1989 to 1991, though significant, are not usually thought of as forces of epochal change. The diagnostic test for emergent world-systems, however construed, must take into account the problem of near-term perspective. 


\section{Conclusion}

Almost daily, we are presented with signs of a system in structural crisis. Politically, there is no shortage of popular protest: in the streets, with Occupy and the Arab Spring; and at the polls with the unforeseen popularity of figures not associated with the liberal center - Jeremy Corbyn and Nigel Farage, Syriza and Golden Dawn, and Bernie Sanders and Donald Trump. The global economy also appears to be in crisis, with unstable economic institutions and sovereign debt emergencies, accompanied by a long-term trend of inequality. But we should take to heart Kenneth Waltz's famous distinction between changes in a system and changes of a system (Waltz 2000). Near-term developments may not be a sign of the end of the modern world-system. If, however, these developments demonstrate the end of endless accumulation or the loss of nation-state dominance, then the modern world-system may indeed be in its final phase. The next task would be to determine what, if any, kind of system has replaced it. Like deep sea creatures, humans may go periods of time without a system. It is quite possible that capitalism will conclude and a long time will pass before it is replaced. ${ }^{34}$ Still, humans may not be like deep sea worms or bacteria, who have to wait patiently - or not so patiently for a whale carcass to sink to the ocean floor. To the contrary, humans may have the capacity to shape the social order during times of systemic transformation. The world they will create, however, remains uncertain.

\section{Acknowledgements}

An earlier draft of this paper was presented in Pittsburgh at the $38^{\text {th }}$ annual Political Economy of the World-System conference. I thank Jackie Smith and the other organizers for a lively and productive three days. I also thank Richard Bownas, Cyrus Ernesto Zirakzadeh, and the editors for their comments.

\section{NOTES}

${ }^{1}$ For the stages of a whale fall, see Smith and Baco 2003. See also Radiolab's interview with Smith in its episode on 'Loops' 2011.

${ }^{2}$ The idea of systems having lives can be attributed the chemist Ilya Prigogine and the social scientist Immanuel Wallerstein, who together realized that they studied similar phenomena: the birth, life, and death, of systems. Wallerstein considered this idea a foundational element of world-systems analysis, writing: 'Premise No. 1 is that all systems - from the astronomical universe to the smallest physical phenomena, and including of course historical social systems - have lives' (2011a: 31).

${ }^{3}$ See my interview with Immanuel Wallerstein 2013.

${ }^{4}$ Readers might prefer to list five or six different branches within the world-systems tradition. They might, for example, point to the 'civilizational' studies of David Wilkinson, or the 'worldecology' perspective of Jason W. Moore as embodying separate schools of thought. Stephen K. Sanderson and Thomas D. Hall identified some seven strains of world-systemic thought. But when it comes to species of world-systems scholarship, my own disposition is more for lumping than splitting. Furthermore, the purpose of this paper is not to distinguish among related paradigms, but to consider ideas relevant to as many branches of world-systems as possible. See Wilkinson 1994; Moore 2015; and Sanderson, Hall 1995.

${ }^{5}$ The most well-known work from this perspective is Chase-Dunn, Hall 1997. The image of rivers and streams comes from Chase-Dunn, Lerro 2014: 78. 
${ }^{6}$ For his most well-known application of world-systems analysis, see Wallerstein 1974a. For an explanation of his perspective, see Wallerstein 1974b.

${ }^{7}$ For an explanation of the generalized crisis of capitalism, see Amin 2011. For an explanation of the nature of systemic transformation, see Chase-Dunn, 2014.

${ }^{8}$ One of the authors, Georgi Derluguian (2016) discussed the book in a response to critics. He titled his piece: 'Does Capitalism Have a Future? That is the Research Question.'

${ }^{9}$ For a discussion of stored value, see Wallerstein, Clesse 2002: 84. For measuring stored value in practice, see Wallerstein 1974a.

${ }^{10}$ This is sometimes called capitalism's 'spatial fix' (Harvey 2001).

${ }^{11}$ For concise summaries of expansion, see Chase-Dunn 1998; Chase-Dunn, Lerro 2014.

${ }^{12}$ The modern world-system is too large, and encompasses too many people, for scholars to think of it in human terms, having passions or fears. But firms, often controlled by a small number of people, can behave as if they have a human desire for survival. Employees and managers alike usually associate their own survival with the survival of the firm.

${ }^{13}$ See, for example, Robert Brenner's assessment of the 1973 global downturn and prospects for an upturn in the twenty-first century. Brenner examines demand, government intervention, stock market profitability, industrial manufacturing, retail, housing, and currency. He concludes, a few years before the 2008 financial crisis, that the global economy was not as stable as it seemed (Brenner 2001; Brenner 2004).

${ }^{14}$ See Kondratieff's essays from the 1920s, reprinted in The Long Wave Cycle (1984)

${ }^{15}$ Although the international and American labor movements has declined in members and power over the last several decades, working class ideals continue to shape ideas about fairness and capitalism on a world-scale. See Fink 2015; Silver 2016.

${ }^{16}$ The others are social upheavals and the biogenetic revolution (Žižek 2010).

17 The best 'transition debate' discussion that I have read can be found in two edited collections: Sweezy, et al. 1976; Aston and Philpin (eds.) 1985)

${ }^{18}$ A leading work in this area is Wallerstein 1980.

${ }^{19}$ As Joseph Canning concludes, although a medieval prince's power was in theory limited by the Church, some, like Charlemagne, proved difficult to restrain in practice (1996: 58). Indeed, Charlemagne considered the empire to be his personal property and, in 806 , drafted a territorial inheritance for each of his three sons. According to Canning, 'Charlemagne believed that he had won his empire for himself with divine approval, and felt in no way dependent on the Roman people or the pope for the source of his power' (Ibid.: 70).

${ }^{20}$ For financial patterns leading to hegemonic rise and decline, see Silver, Arrighi 2011.

${ }^{21}$ For more on this debate, see Ba, Hoffman 2005.

${ }^{22}$ For a collection of documents and a debate on surveillance, including the view that security leaks have harmed U.S. national security, see Fidler 2015.

${ }^{23}$ For an overview of these debates, see the special issue of Review (34, no. 3, 2011), D. O'Hearn, T. M. Wilson, eds., whose view is one of 'The Resiliency of the Nation-State in Scholarship and In Fact.'

${ }^{24}$ Kenneth Waltz's assumption about state behavior can be applied to any institution: 'Beyond the survival motive, the aims of states may be endlessly varied; they may range from the ambition to conquer the world to the desire to merely to be left alone' (1979: 91).

${ }^{25}$ The classification presented draws on those advanced by Wallerstein (1974b) and Chase-Dunn and Hall (1997). It is not an exhaustive list, but a representation of clearly distinct types of worldsystems. 
${ }^{26}$ Although Wallerstein (1974a) formulated the concept of the semiperiphery, he did so in reference to the modern world-system. Later, Chase-Dunn and Hall (1997) applied notions of semiperipherality to premodern world-systems.

${ }^{27}$ See noteworthy accounts by Arrighi 2010 and Wallerstein 1974a.

${ }^{28}$ See the United Nations summary, 'World population projected to reach 9.7 billion by 2050,' released by the Department of Economic and Social Affairs (29 July 2015).

${ }^{29}$ For an elaboration on the conceptual problems related to bulk goods versus necessities see Wallerstein 1989: 131-132.

${ }^{30}$ In the long term, a great deal of human impact on the planet can be reclaimed by the natural world (Weisman 2007).

${ }^{31}$ The entropy of the modern world-system is both literal and figurative: literal, in that the capitalist world-system generates environmental waste; and figurative in that the system is unable to return to a kind of normal condition for the reasons described above. For a discussion of the former, see Kick, McKinney 2012. For a discussion of the latter, see Prigogine 1997.

${ }^{32}$ Wallerstein 2011 b, especially chapter four. For summary and critique of the book, see Williams 2012.

${ }^{33}$ See, once again, the 'Dobb-Sweezy' and 'Brenner' debates (Sweezy, et al, 1976; Aston and Philpin 1985).

${ }^{34}$ Just as there is disagreement about when the modern world-system began, there is a disagreement about whether there must always be a world-system. See, notably, the debate in Frank, Gills, eds. 1993.

\section{REFERENCES}

Amin, S. 2011. Ending the Crisis of Capitalism or Ending Capitalism. Trans. Victoria Bawtree. Cape Town: Pambazuka Press.

Anderson, P. 1974a. Passages from Antiquity to Feudalism. London: Verso.

Anderson, P. 1974b. Lineages of the Absolutist State. London: Verso.

Anderson, P. 1992. English Questions. London: Verso.

Arrighi, G. 2010. The Long Twentieth Century: Money, Power and the Origins of our Times. $2^{\text {nd }}$ ed. London: Verso.

Arrighi, G., and Silver, B. 2001. Capitalism and world (dis)order. Review of International Studies 27: 257-279.

Aston, T. H., and Philpin, C. H. E. (eds.) 1985. The Brenner Debate. Cambridge: Cambridge University Press.

Ba, A. D., and Hoffman, M. J. (eds.) 2005. Contending Perspectives on Global Governance: Coherence, Contestation and World Order. London: Routledge.

Braudel, F. 1982. Civilization and Capitalism, 15 th $-18^{\text {th }}$ Century II: The Wheels of Commerce. S. Reynolds (trans.) New York: Harper \& Row.

Braudel, F. 1984. Civilization and Capitalism, 15 th $-18^{\text {th }}$ Century III: The Perspective of the World. S. Reynolds (trans.) New York: Harper \& Row.

Brenner, R. 2001. The world economy at the turn of the millennium toward boom or crisis? Review of International Political Economy 8 (1): 6-44.

Brenner, R. 2004. New Boom or New Bubble? New Left Review II 25 (January-February): 57-100.

Canning, J. 1996. A History of Medieval Political Thought, 300-1450. London: Routledge.

Carr, E. H. 1961. What Is History? New York: Random House. 
Chase-Dunn, C. 1998. Global Formation: Structures of the World-Economy, $2^{\text {nd }}$ ed. Lanham, MD: Rowman \& Littlefield.

Chase-Dunn, C. 2003. Globalization From Below: Toward a Collectively Rational and Democratic Commonwealth. Social Evolution and History 2 (1): 195-237.

Chase-Dunn, C. 2013. Five Linked Crises in the Contemporary World-System. Journal of World-Systems Research 19 (2): 175-180.

Chase-Dunn, C. 2014. Continuities and Transformations in the Evolution of World-Systems. Journal of Globalization Studies 5 (1): 11-31.

Chase-Dunn, C., and Lerro, B. 2014. Social Change: Globalization from the Stone Age to the Present. Boulder: Paradigm.

Chase-Dunn, C., and Hall, T. D. 1997. Rise and Demise: Comparing World-Systems. Boulder, CO: Westview.

Crevald, M. 1999. The Rise and Decline of the State. Cambridge: Cambridge University Press.

Denemark, R. A. 1999. World System History: From Traditional Politics to the Study of Global Relations. International Studies Review 1 (2): 43-75.

Derluguian, G. 2016. Does Capitalism Have a Future? That is the Research Question. Cliodynamics 7 (1): 109-118.

Fidler, D. P. (ed.) 2015. The Snowden Reader. Bloomington: Indiana University Press.

Fink, L. 2015. The Long Gilded Age. Philadelphia: University of Pennsylvania Press.

Frank, A. G. 1998. ReOrient: Global Economy in the Asian Age. Berkeley: University of California Press.

Frank, A. G., and Gills, B. K. (eds.) 1993. The World System: Five hundred years or five thousand? London: Routledge.

Fukuyama, F. 1992. The End of History and the Last Man. New York: Avon.

Friedmann, H. 2000. What on Earth is the Modern World-System? Foodgetting and Territory in the Modern Era and Beyond. Journal of World-Systems Research 6 (2): 480-515.

Harvey, D. 2001. Globalization and the 'Spatial Fix.' Geographische Revue 2: 23-30.

Klare, M.T. 2012. The Race for What's Left. New York: Metropolitan.

Kick, E. L., and McKinney, L. 2012. World-system structure, natural capital and environmental entropy. In Babones, S. J., and Chase-Dunn, Ch. (eds.), Routledge Handbook of World-Systems Analysis (pp. 392-399). London: Routledge.

Kondratieff, N. 1984. The Long Wave Cycle. G. Daniels (trans.) New York: Richardson and Snyder.

Moore, J. W. 2010. Cheap Food \& Bad Money: Food, Frontiers, and Financialization in the Rise and Demise of Neoliberalism. Review 33 (2/3): 225-261.

Moore, J. W. 2015. Capitalism in the Web of Life. London: Verso.

O'Hearn, D., and Wilson, T. M. (eds.) 2011. The Resiliency of the Nation-State in Scholarship and In Fact. Review 34 (3): 253-331.

Prigogine, I. 1997. The End of Certainty: Time, Chaos, and the New Laws of Nature. New York: The Free Press.

Radiolab. 4 October 2011. Loops: https://www.wnycstudios.org/story/161744-loops.

Sanderson, S. K., and Hall, T.D. 1995. World System Approaches to World-Historical Change. In Sanderson, S. (ed.), Civilizations and World Systems (pp. 95-108). Walnut Creek, CA: Alta Mira. 
Silver, B. 2013. Theorising the Working Class in Twenty-First-Century Global Capitalism. In Workers and Labour in a Globalised Capitalism (pp. 46-69). New York: Palgrave.

Silver, B. 2016. Workers of the World. Jacobin 22 (Summer): 45-54.

Silver, B., and G. Arrighi 2011. The End of the Long Twentieth Century. In Calhoun, C., and Derluguian, G. (eds.), Business As Usual: The Roots of the Global Financial Meltdown (pp. 53-68). New York: New York University Press.

Smith, C. R., and A. R. Baco. 2003. Ecology of Whale Falls at the Deep-Sea Floor. Oceanography and Marine Biology 41: 311-354.

Strange, S. 1996. The Retreat of the State: The Diffusion of Power in the World Economy. Cambridge: Cambridge University Press.

Suter, C. 2012. Debt crises in the modern world-system. In Babones, S. J. and Chase-Dunn Ch. (eds.), Routledge Handbook of World-Systems Analysis (pp. 215-223). London: Routledge.

Sweezy, P., et al. 1976. The Transition from Feudalism to Capitalism. London: Verso.

United Nations. 29 July 2015. World population projected to reach 9.7 billion by 2050 : http:// www.un.org/en/development/desa/news/population/2015-report.html.

Wallerstein, I. 1974a. The Modern World-System I: Capitalist Agriculture and the Origins of the European World-Economy in the Sixteenth Century. New York: Academic Press.

Wallerstein, I. 1974b. The Rise and Future Demise of the World Capitalist System: Concepts for Comparative Analysis. Comparative Studies in Society and History 16 (4): 387-415.

Wallerstein, I. 1980. The Modern World-System II: Mercantilism and the Consolidation of the European World-Economy, 1600-1750. New York: Academic Press.

Wallerstein, I. 1983. The Three Instances of Hegemony in the History of the Capitalist World-Economy. International Journal of Comparative Sociology 24 (1-2): 100-108.

Wallerstein, I. 1984. Long Waves as Capitalist Process. Review 7 (4): 559-575.

Wallerstein, I. 1995. Historical Capitalism with Capitalist Civilization, $2^{\text {nd }}$ ed. London: Verso.

Wallerstein, I. 1989. The Modern World-System III: The Second Era of Great Expansion of the Capitalist World-Economy, 1730-1840s. New York: Academic Press.

Wallerstein, I. 1998. Utopistics, Or, Historical Choices of the Twenty-first Century. New York: The New Press.

Wallerstein, I. 2011a. Structural Crisis in the World-System: Where Do We Go from Here? Monthly Review 62 (10): 31-39.

Wallerstein, I. 2011b. The Modern World-System IV: Centrist Liberalism Triumphant. Berkeley, CA: University of California Press.

Wallerstein, I. 15 April 2013. End of the Road for Runaway Factories? Commentary no. 351. URL: http://iwallerstein.com/road-runaway-factories/.

Wallerstein, I., and Clesse, A. (eds.) 2002. The World We Are Entering, 2002-2050. The Netherlands: Dutch University Press.

Wallerstein, I., Collins, R., Mann, M., Derluguian, G., and Calhoun, C. 2013. Does Capitalism Have a Future? Oxford: Oxford University Press.

Waltz, K. 1979. Theory of International Politics. New York: McGraw-Hill.

Waltz, K. 2000. Structural Realism after the Cold War. International Security 25 (1): 5-41. 
Weber, M. 1946. Class, Status, Party. In Gerth H. H., and Mills, C. W. (trans. and eds.), Essays in Sociology (pp. 180-195). Oxford: Oxford University Press.

Weisman, A. 2007. The World Without Us. New York: Picador.

Wilkinson, D. 1994. Civilizations are World Systems! Comparative Civilizations Review 30: 59-71.

Williams, G.P. 2012. Book Review: The Modern World-System IV. New Political Science 34 (3): 428-431.

Williams, G. P. 2013. Interview with Immanuel Wallerstein: Retrospective on the Origins of World-Systems Analysis. Journal of World-Systems Research 19 (2): 202-210.

Wolff, R. P. 2012. The Future of Socialism. Seattle University Law Review 35: 1403-1428.

Wood, E. M. 2002. The Origin of Capitalism: A Longer View. London: Verso.

Žižek, S. 2010. Living in the End Times. London: Verso. 